\title{
Homology of cryptic plasmid of Neisseria gonorrhoeae with plasmids from Neisseria meningitidis and
}

\section{Neisseria lactamica}

\author{
CATHERINE A ISON, * C M BELLINGER, ${ }^{*}$ J WALKER† \\ From the *Department of Medical Microbiology, St Mary's Hospital Medical School, London, and \\ $\dagger$ †iagnostics, Wellcome Research Laboratories, Beckenham, Kent
}

SUMMARY DNA probe hybridisation was used to examine the relation between the cryptic plasmid from Neisseria gonorrhoeae and plasmids carried by pharyngeal isolates of Neisseria meningitidis and Neisseria lactamica. The complete gonococcal cryptic plasmid and HinfI derived digestion fragments subcloned into Escherichia coli were used to probe Southern blots of plasmid extracts. Homology was found to a plasmid of approximate molecular weight 4.5 kilobase pairs $(\mathrm{Kb})$ but not to plasmids of $<3.2 \mathrm{~Kb}$ or $6.5 \mathrm{~Kb}$. Eleven of 16 strains of $N$ meningitidis and two of six strains of $N$ lactamica carried plasmids that showed strong hybridisation with the $4.2 \mathrm{~Kb}$ gonococcal plasmid. Hybridisation of plasmids from non-gonococcal species of neisseria with the gonococcal cryptic plasmid indicates that caution should be taken when using the cryptic plasmid as a diagnostic probe for gonorrhoea.

The genus Neisseria contains two pathogenic species, Neisseria meningitidis and Neisseria gonorrhoeae. $N$ meningitidis colonises the upper respiratory tract and invades to produce systemic disease, whereas $\mathrm{N}$ gonorrhoeae infects the columnar epithelium of the genital tract and rectum and only rarely causes systemic disease. Other species of neisseria have occasionally been associated with infection but are generally regarded as commensals. ${ }^{1}$ Within the genus there is strong DNA homology between the species, ${ }^{2}$ which is highest between $N$ meningitidis and $N$ gonorrhoeae ( $>$ $80 \%$ ). Despite their close genetic association pathogenic neisseria can be distinguished from commensal neisseria by their ability to produce IgAI protease, ${ }^{3}$ adhere to columnar epithelium, ${ }^{4}$ and produce an outer membrane antigen designated $\mathrm{H}^{5} .^{5} \mathrm{~N}$ meningitidis and $N$ gonorrhoeae differ from each other in their ability to utilise carbohydrates, requirement for cysteine and cystine, and their aminopeptidase profiles. ${ }^{6}$ In most clinical laboratories only the ability of $N$ meningitidis to produce acid from maltose in addition to glucose is routinely used for differentiation.

A major distinguishing factor is the carriage of plasmids by strains of $N$ gonorrhoeae. ${ }^{7}$ Several plas-

Accepted for publication 8 May 1986 mids have been isolated; a cryptic plasmid, molecular weight $4.2 \mathrm{~Kb}$; a conjugal plasmid $(37 \mathrm{~Kb})$; and two penicillinase coding plasmids $(7 \cdot 1 \mathrm{~Kb}$ and $5.6 \mathrm{~Kb})$. In contrast, there have been only a few reports of plasmids in meningococci. ${ }^{8-13}$ Commensal neisseria have also been reported to carry plasmids. ${ }^{7}$

DNA probes are being introduced for the detection and identification of micro-organisms. The specificity of any such probe depends on the choice of a suitable piece of DNA present in the organism to be detected. The cryptic gonococcal plasmid, which is carried by at least $90 \%$ of strains ${ }^{14}$ has the potential to fulfil this criterion. Totten et al ${ }^{15}$ described the use of a cryptic plasmid probe to detect $N$ gonorrhoeae in urethral exudate from men and it has also been used in combination with a penicillinase coding plasmid probe on clinical samples. ${ }^{16}$

We used subcloned fragments, as well as the entire plasmid, to determine the homology between the cryptic gonococcal plasmid and low molecular weight plasmids carried by throat isolates of $N$ meningitidis ${ }^{1213}$ and $N$ lactamica.

\section{Material and methods}

BACTERIAL STRAINS

Sixteen strains of $N$ meningitidis and six strains of $N$ 
lactamica known to carry plasmids were studied. All strains were originally isolated from the throat of patients attending a sexually transmitted disease clinic. They were collected during studies for screening throat isolates of neisseria for plasmid carrying strains. ${ }^{13}$

$N$ gonorrhoeae, strain $38 / 2$, was used to prepare the probes and was kindly provided by Dr P Novotny, Wellcome Research Laboratories. Strain HI, a laboratory strain from St Mary's, which carries the $4.2 \mathrm{~Kb}$ cryptic plasmid, was used as a reference on Southern blots.

Escherichia coli, strain TG1, was used in subcloning experiments.

\section{MEDIA}

Strains were initially isolated on GC agar base (Difco), $36 \mathrm{~g} / \mathrm{l}$, with the addition of $1 \%$ IsoVitalex (BBL) and vancomycin, colistin, trimethoprim, and amphotericin after incubation at $36^{\circ} \mathrm{C}$ in $7 \%$ carbon dioxide for 48 hours. All further subcultures were made on GC agar base with the addition of Kellogg's supplements. ${ }^{17}$

\section{IDENTIFICATION}

Strains were identified as either $N$ meningitidis or $N$ lactamica, if they were Gram negative cocci, oxidase positive, and produced acid from glucose and maltose but not sucrose. Carbohydrate utilisation tests were performed on serum free medium containing glucose, maltose, and sucrose poured into petri dishes. ${ }^{18}$

$N$ lactamica strains were distinguished from those of $N$ meningitidis by their ability to split onitrophenyl-galactoside, as previously described. ${ }^{12}$ All strains were examined for their aminopeptidase profiles $^{19}$ and their ability to grow in the absence of cysteine and cystine. ${ }^{20}$ The Phadebact GC monoclonal test (Pharmacia) was used to detect the presence of gonococcal antigens. This reagent contains antibodies that are directed against two epitopes of the gonococcal outer membrane protein (OMP-PI).

\section{PLASMID EXTRACTION}

Plasmids were isolated from strains of neisseria by the alkali extraction method of Birnboim and Doly. ${ }^{21} \mathrm{~A}$ modification of this technique ${ }^{22}$ was used for large scale preparation of the cryptic plasmid from $N$ gonorrhoeae and of its subclones grown in $E$ coli strain TG1. For large scale plasmid extraction, cells of $N$ gonorrhoeae $(38 / 3)$ were obtained by scraping growth from GC medium, while $E$ coli strain TG1 was pelleted after growth in shake flasks of LB broth. ${ }^{22}$

Plasmids used for subcloning and as probes were further purified by centrifugation through caesium chloride-ethidium bromide density gradients.

\section{SUBCLONING}

The methods for the manipulation of DNA were as described by Maniatis et al. ${ }^{22}$ Based on a previously published restriction enzyme map of the cryptic plasmid of $N$ gonorrhoeae ${ }^{23}$ the density gradient purified plasmid was digested with Hinfl, yielding two fragments of 2.6 (large) and 1.7 (small) kilobase pairs. The fragments were blunt ended using the Klenow fragment of polymerase I, then ligated with the plasmid vector pUC-8, which had been SMA I digested.

The ligation mixture was used to transform competent cells of $E$ coli strain TG1. Transformants selected on LB plates containing ampicillin, were screened by colony blots with nick translated large and small fragment probes.

Clones of pUC-8 containing the small fragment (pGC1) and large fragment (pGC3) of the cryptic plasmid from $N$ gonorrhoeae were used for the preparation of plasmid probes.

\section{PLASMID ANALYSIS}

Plasmids were electrophoresed in $1 \%$ agarose, as previously described. ${ }^{12}$ Triplicate gels were prepared, and, following staining by ethidium bromide and photography, the DNA was transferred to nitrocellulose membranes by Southern blotting. ${ }^{24}$ DNA was fixed to the membranes by baking for two hours at $80^{\circ} \mathrm{C}$ in a vacuum oven.

\section{NICK TRANSLATION}

The cryptic plasmid of $N$ gonorrhoeae and its subclones pGC1 and pGC3 were labelled with $\alpha-{ }^{32}$ P-dATP by nick translation, using a commercially available kit (Amersham International) to a specific activity of $4 \times 10^{7}-2 \times 10^{8} \mathrm{dpm} / \mu \mathrm{g}$ DNA.

\section{HYBRIDIS ATION}

Membranes were prehydridised for three hours at $37^{\circ} \mathrm{C}$ in a solution containing $50 \%(\mathrm{v} / \mathrm{v})$ deionised formamide; $4 \times$ SSC $(1 \times$ SSC $=0.15 \mathrm{M}$ sodium chloride, $0.015 \mathrm{M}$ sodium citrate, $\mathrm{pH} 7.0$ ); $0.1 \%$ sodium dodecyl sulphate; $1 \times$ Denhardt's solution $(0 \cdot 1 \%$ Ficoll, $0 \cdot 1 \%$ polyvinylpyrolidone, and $0 \cdot 1 \%$ bovine serum albumin); and $100 \mu \mathrm{g} / \mathrm{ml}$ denatured salmon sperm DNA. About $1 \times 10^{6} \mathrm{dpm}$ of heat denatured probe was added to each membrane in $1 \mathrm{ml}$ of the above hybridisation solution and incubated at $37^{\circ} \mathrm{C}$ overnight. Triplicate membranes were probed with either the cryptic plasmid, pGC1, or pGC3. Membranes were then washed in four changes of 0.2 $\times$ SSC at room temperature before autoradiography at $-70^{\circ} \mathrm{C}$ using $x$ ray film (X-OmatS, Kodak) with an intensifier screen. Usually four to five hours' exposure was required. 


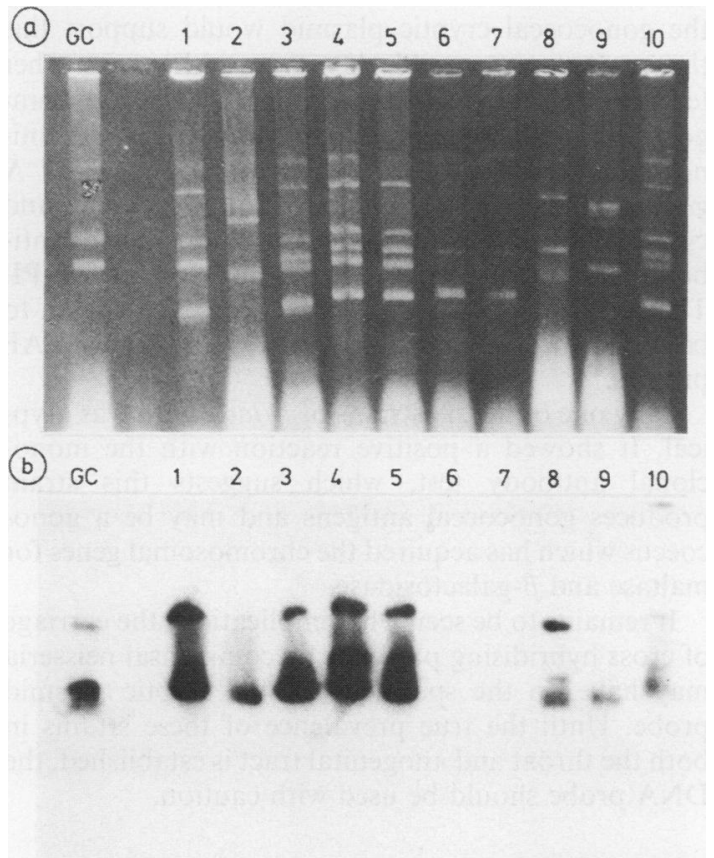

Fig 1 (a) agarose gel electrophoresis; (b) autoradiograph of Southern blot of $(a)$ probed with complete cryptic plasmid probe. GC represents $N$ gonorrhoeae, strain H10. Tracks $1-5,8$ and 10 are strains of $N$ meningitidis; tracks 6,7 , and 9 are strains of $N$ lactamica.

Results

All strains of $N$ meningitidis and $N$ lactamica were identified by carbohydrate utilisation and ability to split ONPG. The aminopeptidase profile, ability to

Table 1 Characteristics of plasmid carrying strains of $N$ meningitidis and $N$ lactamica

\begin{tabular}{llll}
\hline & \multicolumn{2}{l}{$N$ meningitidis } & $N$ lactamica \\
\cline { 2 - 4 } \cline { 2 - 4 } & \multicolumn{2}{l}{ No of strains showing positive reaction } \\
\hline Total & 13 & 3 & 6 \\
$\begin{array}{l}\text { Aminopeptidase activity } \\
\text { Glutamyl }\end{array}$ & 13 & 0 & 0 \\
$\begin{array}{l}\text { Hydroxyproline } \\
\text { GC monoclonal reagent }\end{array}$ & 0 & 3 & 6 \\
Requirement for \\
cysteine and cystine & 0 & 0 & 1 \\
\hline
\end{tabular}

grow in the absence of cysteine and cystine, and Phadebact GC monoclonal test were used to detect any unusual features in these strains. Thirteen of the 16 meningococci showed a typical aminopeptidase profile - that is, glutamyl aminopeptidase activity but not hydroxyproline aminopeptidare activity (table 1). The remaining three strains showed the converse, which is typical of $N$ gonorrhoeae or $N$ lactamica. None of the meningococci showed a positive reaction with the Phadebact GC monoclonal reagent or required cysteine and cystine for growth.

All strains of $N$ lactamica had a typical aminopeptidase profile and did not require cysteine and cystine for growth. One of the six strains, however, gave a strong positive reaction with the Phadebact GC monoclonal test.

Several plasmids were isolated from these neisseriae, of approximate molecular weight $<3 \cdot 2,4 \cdot 5$, and $6.5 \mathrm{~Kb}$, either alone or in combination. The ability of these plasmids to hybridise with radiolabelled probes of the whole cryptic plasmid and the large (pGC3) and small (pGCl) fragment subclones was tested by Southern blotting. Only $4.5 \mathrm{~Kb}$ plasmids showed homology (figure) whether present alone or in combination with lower molecular weight plasmids (table 2). All strains carrying $4.5 \mathrm{~Kb}$ plasmids, however, showed hybridisation. Strains that showed hybridisation with the complete cryptic plasmid also showed strong hybridisation with both the $\mathrm{pGCl}$ and pGC3 subclones. Higher stringency washes of $0.2 \times$ $\mathrm{SSC}$ at $55^{\circ} \mathrm{C}$ did not remove the probes. Cross hybridisation was not observed between the pUC-8 vector and strains of either gonococci or other species of neisseria. This indicates that observed hybridisation was the result of homology between the subcloned fragments and plasmids from neisseria.

There was no homology between the group of plasmids of $<3.2 \mathrm{~Kb}$ or $6.5 \mathrm{~Kb}$ and the cryptic plasmid probe in any of the extractions (figure).

\section{Discussion}

We showed the presence of plasmids in 11 strains of $N$ meningitidis and two strains of $N$ lactamica that show homology with the gonococcal cryptic plasmid. The plasmids also hybridise strongly with the two sub-

Table 2 Hybridisation between plasmids carried by $N$ meningitidis and $N$ lactamica and cryptic plasmid probe*

\begin{tabular}{|c|c|c|c|c|}
\hline \multirow[b]{2}{*}{ Plasmid $(K b)$ present } & \multicolumn{2}{|c|}{$N$ meningitidis } & \multicolumn{2}{|c|}{$N$ lactamica } \\
\hline & Total & No showing homology & Total & No showing homology \\
\hline $\begin{aligned}< & 3.2 \text { alone } \\
& 4.5 \text { alone } \\
< & 3.2+4.5 \\
& 6.5\end{aligned}$ & $\begin{array}{l}4 \\
4 \\
7 \\
1\end{array}$ & $\begin{array}{l}0 \\
4 \\
7 \\
0\end{array}$ & $\begin{array}{l}4 \\
1 \\
1 \\
0\end{array}$ & $\begin{array}{l}0 \\
1 \\
1 \\
0\end{array}$ \\
\hline
\end{tabular}

*Concordant results were obtained with the subclones of the cryptic plasmid. 
cloned fragments created by Hinfl digestion of the cryptic plasmid. Higher stringency washes did not remove probes from Southern blots. We suggest that this strongly indicates a large degree of homology rather than cross hybridisation with a small portion of DNA. Preliminary experiments, in which Southern blots of restriction fragments from the cryptic plasmid have been probed with plasmids from commensal strains, have also shown a large degree of homology. Further work, however, is required to determine accurately the extent of homology. The new plasmids are usually slightly larger, about $4.5 \mathrm{~Kb}$, than the gonococcal cryptic plasmid. This may be due to extra or inverted repeat segments. ${ }^{23}$

Attempts to size accurately the plasmid from one particular strain have been hampered because the plasmid does not seem to be readily digested by a selection of restriction endonucleases. ${ }^{13}$

There was no homology between any of the probes used and the plasmids of molecular weight $<3.2 \mathrm{~Kb}$. These plasmids seem to vary in size, without any particular size being restricted to strains of either $N$ meningitidis or $N$ lactamica.

We experienced difficulty in maintaining plasmids during storage of some of these strains at both $-70^{\circ} \mathrm{C}$ and in liquid nitrogen. Their function is unknown and therefore we were unable to maintain by selection. This differs from the gonococcal cryptic plasmid, which is stable on storage and subculture.

The use of the cryptic plasmid as a DNA probe to detect gonococci in clinical samples has two major problems. Firstly, the sensitivity depends on the presence of the plasmid in all strains of $N$ gonorrhoeae. Isolates that require proline, citrulline, and uracil for growth are known not to carry the cryptic plasmid, although the numbers of these isolates are usually low. ${ }^{14}$ Secondly, the specificity depends on the DNA sequence on the cryptic plasmid being unique to gonococci. Totten et al ${ }^{15}$ showed homology between 124 of 134 strains of $N$ gonorrhoeae, one of 11 strains of $N$ mucosa, and one of seven strains of $N$ cinerea tested. We show homology between plasmids carried by meningococci and $N$ lactamica isolated from the throat of patients attending a sexually transmitted disease clinic. In unpublished observations (CA Ison and $\mathrm{CM}$ Bellinger) the prevalence of plasmid carrying strains was $5 \%$ of throat meningococci and $4 \%$ of anogenital meningococci tested. Unfortunately, plasmids from anogenital strains were not available for testing with the probes.

We have previously suggested that gonococci may accept chromosomal DNA from mouth flora by transformation in vivo, and consequently the ability to utilise maltose. They may then become misidentified as meningococci. Our finding in this study of a plasmid in meningococci with homology to the gonococcal cryptic plasmid would support this theory. It was impossible, however, to show any other features common to gonococci in 13 of the 16 meningococci. The three remaining meningococci had aminopeptidase profiles that were more typical of $N$ gonorrhoeae, but they did not require cysteine and cystine for growth or react with monoclonal antibodies to the gonococcal outer membrane protein-PI Throat meningococci have previously been shown to be a heterogeneous group and to have atypical AP profiles. ${ }^{12}$

Only one of the six strains of $N$ lactamica was atypical. It showed a positive reaction with the monoclonal antibody test, which suggests this strain produces gonococcal antigens and may be a gonococcus which has acquired the chromosomal genes for maltase and $\beta$-galactosidase.

It remains to be seen what implications the carriage of cross hybridising plasmids by commensal neisseria may have on the specificity of the cryptic plasmid probe. Until the true prevalence of these strains in both the throat and anogenital tract is established, the DNA probe should be used with caution.

\section{References}

1 Johnson AP. The pathogenic potential of commensal species of Neisseria. J Clin Pathol 1983;36:213-23.

2 Hoke C, Vedros NA. Taxonomy of the Neisseriae: deoxyribonucleic acid base comparison, interspecific transformationand deoxyribonucleic acid hybridisation. Int J System Bac-? teriol 1982;32:57-66.

3 Plaut AG, Gilbert JV, Artenstein MS, Capra JD. Neisseria gonorrhoeae and Neisseria meningitidis: extracellular enzyme cleaves human immunoglobulin A. Science 1975;190:1103-5.

4 McGee ZA. Stephens DS, Melly MA, Gregg CR, Schlech WF Hoffman LH. Role of attachment in the pathogenesis of disease caused by Neisseria gonorrhoeae and Neisseria meningitidis. In: Schlessinger D, ed. Microbiology 1982. Washington D.C.: American Society for Microbiology, 1982:286-91.

5 Cannon JG. Black WJ, Nachamkin I, Stewart PW. Monoclonal antibody that recognises an outer membrane antigen common to pathogenic Neisseria species but not to most nonpathogenic Neisseria species. Infect Immun 1984;43:994-9.

6 D'Amato RF, Eriquez LA, Tomfohrde KM, Singerman E. Rapid identification of Neisseria gonorrhoeae and Neisseria meningitidis by using enzymatic profiles. $J$ Clin Microbiol 1978;7:77-81.

7 Elwell LP, Falkow S. Plasmids of the genus Neisseria. In: Roberts RB, ed. The gonococcus. London: Wiley \& Son, 1977;137-54.

8 Bhatti AR, O'Hara K, White LA, Bryan LE. Presence of plasmid deoxyribonucleic acid in Neisseria meningitidis. Federation of European Microbiological Societies Microbiology Letters 1981;10:175-7.

9 Verschueren H, Dekegel M, Dekegel D, Gilquin C, DeMayer S. Plasmids in Neisseria meningitidis. Lancet 1982;i:851-2.

10 Dekegel M, Dekegel D. Les plasmids chez Neisseria meningitidis. Med Trop 1983;43:149-52.

11 Dillon JR, Pauze M, Yeung KH. Spread of penicillinaseproducing and transfer plasmids from the goncoccus to Neisseria meningitidis. Lancet 1983;i:779-81.

12 Ison CA, Bellinger CM, Glynn AA. Plasmids in throat and geni- 
tal isolates of meningococci. J Clin Pathol 1984;37:1123-8.

13 Ison CA, Bellinger CM, Easmon CSF. Plasmids in meningococci. In: Schoolnik GK, ed. The pathogenic neisseriae. Washington D.C.: American Society for Microbiology, 1985:216-8.

14 Dillon JR, Pauze P. Relationship between plasmid content and auxotype in Neisseria gonorrhoeae. Infect Immun 1981;33: 625-8.

15 Totten PA, Holmes KK, Handsfield HH, Knapp JS, Perine PL, Falkow S. DNA hybridization technique for the detection of Neisseria gonorrhoeae in men with urethritis. $J$ Infect Dis 1983; 148:462-71.

16 Perine PL, Totten PA, Holmes KK, et al. Evaluation of a DNAhybridisation method for detection of African and Asian strains of Neisseria gonorrhoeae in men with urethritis. $J$ Infect Dis 1985:152:59-63.

17 Kellogg DS, Peacock WL, Deacon WE, Brown L, Pirkle CI. Neisseria gonorrhoeae. I. Virulence genetically linked to clonal variation. J Bacteriol 1963;85:1274-9.

18 Flynn J, Waitkins SA. A serum-free medium for testing fermentation reaction in Neisseria gonorrhoeae. J Clin Pathol 1972;25:525-7.

19 Ison C, Glynn AA, Bascomb S. Acquisition of new genes by oral Neisseria. J Clin Pathol 1982;35:1153-7.
20 Catlin BW. Nutritional profiles of Neisseria gonorrhoeae, Neisseria meningitidis and Neisseria lactamica in chemically defined media and the use of growth requirements for gonococcal typing. J Infect Dis 1973;128:178-94.

21 Birnboim HC, Doly J. A rapid alkaline extraction procedure for screening recombination plasmid DNA. Nucleic Acids Res 1979;7:1513-23.

22 Maniatis T, Fritisch TF, Sambrook J. Molecular cloning: a laboratory manual. New York: Cold Spring Harbour, 1982.

23 Davies JK, Normark S. A relationship between plasmid structure, structural lability and sensitivity to site specific endonucleases in Neisseria gonorrhoeae. Molecular and General Genetics 1980;177:251-60.

24 Southern EM. Detection of specific sequences among DNA fragments separated by gel electrophoresis. J Mol Biol 1975;98:503-17.

Requests for reprints to: Dr Catherine A Ison, Department of Medical Microbiology, Wright Fleming Institute, St Mary's Hospital Medical School, London W2 1PG, England. 